\title{
Defining the Current Practice of Facilities Management Service Delivery in Klang Valley (KV) Shopping Centres
}

\author{
${ }^{1}$ Norafiziah Mohd.Nur, ${ }^{2}$ Zairul Nisham Musa \\ Department of Estate Management, Faculty of Built Environment, University Malaya \\ Email:므orae990@yahoo.com, $\underline{\text { zairul@um.edu.my }}$
}

\begin{abstract}
The study on facilities management (FM) service delivery, especially in shopping centres, covered Klang Valley area rarely found in previous literature. This paper is imperative in helping the facilities management industry to understand more about the perceptions of the shopping centres, industry and their requirements towards FM services in shopping centres in order to deliver quality, innovative, cost effective and best in value services. Questionnaire survey is used as the tool to collect the primer data. Data collected includes the types of FM services, current FM service provision, the criticality of FM service towards overall business operation. The sample size for this survey is 108 shopping centre, which was chosen randomly among all shopping centres within the Klang Valley areas. The findings from this research showed that there are 11 types of FM services currently being practiced in Klang Valley (KV) shopping centres. The most critical FM services are determined according to each size of the shopping centre. It is confirmed that the shopping centres in Klang Valley deliver the FM services using both provisions that include in-house and outsourcing. However, the majority of Klang Valley shopping centre management is still favored in-house FM service delivery as compared to outsourcing.
\end{abstract}

Keywords Facilities Management Services, Service Delivery, Outsourcing, In-House, Shopping Centre

\section{INTRODUCTION}

Facility management (FM) has emerged rapidly as one of the fastest growing and gradually gained a grip as a discipline and profession within the industry (BIFM, 2010; IFMA, 2010; Tay and Ooi, 2001). Although FM is a relatively young industry, but it has shown positive growth in Singapore, Hong Kong, Australia, Japan and Australia apart from the UK and US (Kamaruzzaman and Zawawi, 2010). There are recognized this profession as an activity that can achieve more effective management of the building, services, and associated personnel, in support of the strategic objectives of an organization (Kamaruzzaman and Zawawi, 2010; Nik Elyna and Pitt, 2014).

In Malaysia, the reason why FM is difficult to analyse is because there is no specific organization to provide guidelines and control on the quality and performance of the FM practice. Thus, no comparisons can be made as no specific structure can be used to benchmark the FM practice performance and Adnan, 2008; Syed Mustapha, S.A.H., \& Jusoff, K, 2009). People would always express their views in the media with regards to 
the quality services rendered by a certain organization (Ghani, M.K et al., 2013). According to Ruslan (2007), the key issue currently plaguing FM in Malaysia is low service quality and performance.

The practice of FM in the Malaysian property sector is being widely adopted by a hospital or health care (Haris, S.A., 2008; Syed Mustapha, S.A.H., \& Jusoff, K, 2009). Healthcare is considered as a very important organization and had been recognized as providing medical care for people. Thus, service delivery and performance in healthcare sector required most sophisticated approach compared with other organization (Ghani, M.K et al., 2013). Ever since most hospitals or healthcare in Malaysia is dominantly managed with the FM concept (Syed Mustapha, S.A.H., \& Jusoff, K, 2009; Khoo, E, 2013).

Although health care is dominantly managed with FM concept, the retail sector, unfortunately, received relatively less attention than it should. The main reason is that the facilities management services initially were not completely understood within the shopping centre industry. Therefore, the investors and retailers' expectations were not fully cascaded into the FM provider market (Cant, 2005; Musa and Pitt, 2009).

Moreover, there were limited research studies within this subject area has been identified. This is because most of the previous researches on facilities management identified relate to the medical sector, hotel industry, educational, commercial office building and also industrial. Therefore, the current information needed with regards to this research is less available in the literature. The limitation of the current information available within this subject area has still given the researcher the opportunity to carry out the exploratory survey towards the shopping centre industry. Therefore, this paper aims to identify the current practice of facilities management services that includes the types of FM services available, the current FM service provision, the current options of FM service delivery in Klang Valley shopping centres.

\section{LITERATURE REVIEW}

\subsection{The Various Concept And Wide Definition Of Facilities Management}

Researchers and practitioners have provided numerous definitions of FM which specify mostly about the objectives, as well as the wide scope of FM (Kurdi et.al, 2011, Musa, 2011). However, among all those definitions, it shows that there is a widespread variation on the understanding and how FM actually operates in the industry (Tay and Ooi, 2001).

Due to the identity crisis of FM as mentioned by Price (2002) and Yiu (2008), Tay and Ooi (2001) argue that this is because of the unrecognized FM as a new discipline compared to other management disciplines. For all that, Tan and Ooi (2001), and revised by Noor and Pitt (2010) were formed out with the summary of a various definition of FM from many sources (see Table 1).

Table 1: Facilities Management various definitions.

\begin{tabular}{|c|c|}
\hline $\begin{array}{l}\text { Researchers/ } \\
\text { Organization }\end{array}$ & FM Definitions \\
\hline $\begin{array}{l}\text { Noor and Pitt } \\
(2009) \text {, } \\
\text { Atkins and } \\
\text { Brooks (2005) }\end{array}$ & $\begin{array}{l}\text { Creating an environment that is cohesive to carry out the organization } \\
\text { primary operation, taking an integrated view of the services infrastructure, } \\
\text { deliver customer satisfaction and provide the best value through support and } \\
\text { enhancement of the core business. }\end{array}$ \\
\hline
\end{tabular}

http://e-journal.um.edu.my/publish/JSCP/ 


\begin{tabular}{|c|c|}
\hline $\begin{array}{l}\text { British } \\
\text { Institutions of } \\
\text { Facilities } \\
\text { Management } \\
\text { (BIFM, 2010) }\end{array}$ & $\begin{array}{l}\text { FM is the integration of processes to maintain and develop the agreed } \\
\text { services within an organization. }\end{array}$ \\
\hline $\begin{array}{l}\text { Facilities } \\
\text { Management } \\
\text { Association (UK) } \\
\text { (FMA, 2010) }\end{array}$ & $\begin{array}{l}\text { FM is the efficient integration of support services within the organization } \\
\text { environment. This is essential to the success of the organizational } \\
\text { performance. }\end{array}$ \\
\hline $\begin{array}{l}\text { Kamaruzzaman } \\
\text { and Zawawi } \\
(2010)\end{array}$ & $\begin{array}{l}\text { A balance between technical, managerial and business that may be related to } \\
\text { operational, tactical and strategic decision-making process. }\end{array}$ \\
\hline
\end{tabular}

(Source: Author compilation, 2016)

\subsection{Overview of Facilities Management in Malaysia}

FM in Malaysia is described as a second wave market by the FM industry compared to other countries in Western and Asia Pacific region (Moore and Finch, 2004; Nik Elyna and Pitt, 2014). However, the research findings from Nik Elyna and Pitt (2014) identified that Malaysian seems to confuse over FM identity. FM appears to be presumed as a subset of the property management profession.

However, as stated by Jensen, (2011), facilities management itself has close relations with the main core operation of the organization and not useful during the maintenance period only. Indeed, this perception is supported by Alexander (1996) who declare that the scope of facilities management is very wide and it can be decisive to the organization's goal, vision, and mission.

Back to the Sixth Malaysian Plan (1990-1995) where Malaysia has experienced increasing demand for services mainly in the operation and maintenance of physical assets. This has created a lot of economic activity in the private sectors to undertake non-technical services contracting mainly in publicly-owned building and infrastructure. The individual maintenance contractors provided with services focusing on specific tasks such as those related to engineering works such as mechanical, electrical, and civil engineering, cleaning and hygiene, landscaping, waste disposal and much more.

Meanwhile, during the Seventh Malaysian Plan (1996-2000), the demand for maintenance contractor increase tremendously. This is due to the development and completion of mega projects such as KLIA and National Sports Complex Bukit Jalil in 1998, Petronas Twin Towers and Putrajaya in 1999. It was during this period, Malaysia was introduced to facility management.

At present, the practice of Facility Management in Malaysia is undertaken by Real Estate Firms. This is due to the fact that high-rise buildings such as office towers, residential building are managed by property consultants. Normally, the property companies will provide services such as property and building management as well as simple operations and maintenance of the building (Haris \& Adnan, 2008).

The increasing awareness on the importance of a proper maintenance management system becomes the main contributing factor in the development of FM in Malaysia. The business management of various organizations has started to promote the need for facilities management as part of the business organization. Yet, these 
professions are not specifically deliberate to cover the required skills and knowledge of FM (Haris \& Adnan, 2008).

\subsection{Defining the Type of Facilities Management services}

Effective FM encompasses multiple of activities under one building with several disciplines, combining resources and hence is important to the success of any organization (Musa and Pitt, 2009). To gauge the effectiveness of FM, it is necessary to understand the current conditions of the facility and able to postulate any changes in facilities management practices in order to achieve the desired performance (Lavy and Shohet, 2010).

FM services typically include repairs and maintenance of the building; grounds services; utility management; occupational, environmental safety and health; transportation, car park and public safety; information technology and communications; architectural, engineering and construction services. Every property is different and hence, some of these functions may be applied and some don't depend on the organizational structure.

Underpinning the importance of the FM function to the organization, it is easy to say that facilities management usually covers all non-core activities of an organization (Kurdi et al., 2011). Typically FM might be split into areas of hard and soft services. These possibilities will include housekeeping, mechanical and electrical engineering, cleaning, waste management, security, landscape and gardening, energy management, health, safety and other services too (Cant, 2005). All the stated activities are the most required and crucial to any business organization depending on their own priority (Muhlebach and Alexander, 2005).

\subsection{Facilities Management Service Delivery Model}

Atkins and Brooks (2005) \& Olajide et al (2013) in their paper emphasizes that facilities management functions may success when performed either by the in-house or outsourcing approach. It is still depending on the core priority of the organization. There are only two options available in decision making either to practice in-house or to outsource the services. Some organization prefers and decided to retain the services in-house on the whole basis or outsourcing all the available services on the whole basis. However, there is also another organization retain certain services in-house and outsourcing the other part to outside service provider. Hence, any decision made by the management should be made regards to paths that lead to long-term benefits for the organizations.

There are many discussions and debate regarding the range of options relating to the various combinations of service delivery, which can be applied by the organization (Payne, 2000; Musa, 2011) such as:

- In-house services vs. outsource service

- Single service contract vs. bundled service contract

- Management Contract

- Managing Agents

- Total facilities management (TFM)

Both in-house and outsource services are considered as traditional FM service delivery practices. While for TFM considered as a new type of service delivery in which often associated with FM innovation (Barrett and Baldry, 2009). However, because of the diverse option of service delivery practices available, has caused numerous opinions in selecting the best option. Hence, this uncertainty may indirectly contribute to poor 
performance of service delivery, besides, could affect the development of services strategy for the organizations. (Chieng, 2013).

Cant (2005) argue that the decision to keep all the activities in-house is apparently not helping in reducing the cost and seems to be relatively static and standard fashion. Since then, the trend has changed from the in-house option into outsourcing to various contractors.

\subsection{In-house Service vs Outsource Service}

There are many definitions from previous researchers arises regarding in-house service. Barrett and Baldry (2003) stated that in-house approach is services that employed by the organization under the direct relationship between employer and employee. The management team also appointed by the company itself and the maintenance work carried out using their own manpower (Kurdi et al, 2011). Besides, in-house services mostly cover all the daily operations and some minor works that can rectify by own maintenance staff (Mclvor, 2000).

According to Brandes et al, 1997, Barret and Baldry (2000), Kremic and Tukel (2006) and Wise (2007) they have stated a few reasons why management kept their services done by the internal staff instead of hiring an outside service provider. The reasons are:

- Improving the performance and flexibility of the organization

- Reducing the management responsibility or burden by sourcing out some of the services to outside provider

- Given the management more time to focus on the high priority work or the core business of the organization.

- Offered the company to grow their own internal staff instead of hiring from outside service provider.

- Reduce any risks given from the outside providers.

However, Connors (2003) and Atkins and Brooks (2005) also identified some potential disadvantages or risks of practicing in-house services to shopping centre, which are;

- Hard to measure the performances of the in-house staff if there are no proper segregation of duties and responsibilities.

- The prolonged used by out-dated concepts and technologies.

- Increasing the management burden and given a lot more workload to handle.

In contrary, according to Rodriguez and Diaz (2008), outsourcing is the practice of "contracting out" services to an external source and hence involves the transfer of responsibilities (Krell, 2006). Other than that, outsourcing also is a process where the user employs outside company or provider to perform a function which previously carried out in-house by the internal staff (Barrett and Baldry, 2003). The definition supported or corroborates by Atkin (2003) state that outsourcing is a situation where an organization has to hands over the facilities management services to the external service providers.

Not all services can be done and rectify by the management team themselves. They have many other responsibilities to be handled and at the same time to make people satisfied with the service provided. According to Elmuti (2003), there is some of the services need to be outsourced and handled by the outside service providers. Besides that, there are also a few top reasons for undertaking outsourcing as cited in Elmuti (2003) as follow; 
- Some resources not available internally

- Require skills and specialists from outside which not available internally

- Some services are difficult to manage by internal staff

- Facilitating access to updated technologies

- Improve delivery, reliability and service quality.

- Better access to better quality. Beside by outsourcing, it may reduce the risk of using outdated facilities equipment.

There are also potential risks or disadvantages of outsourcing that have to be considered by the shopping centre managers. Collings (2007); Barrett and Baldry (2003) have identified some problems from own experience regarding outsourcing as follow:

- Outsourcing might not always cost effective due to claimed savings based on forecast hopes.

- The management team may select a poor supplier or unable to control the suppliers.

- Too much outsourcing services may cause the organization to lose their in-house expertise or capability.

- The outsourcing provider might not able to cope with volume of activities

\section{METHODOLOGY}

This research adopted the quantitative method as an appropriate method in order to achieve the research aim and objectives. The questionnaire survey is used as a tool to collect the primary data as to investigate the current FM service delivery practiced in Klang Valley shopping centres. The questionnaire survey is distributed directly to the respondents to get a quick response. The respondents are the shopping centre managers as they usually involved and responsible in making decision for the best procurement. All the data obtained are analysed using descriptive statistics with the help of the Statistical Package for Social Science (SPSS®) software.

The questionnaire was designed and consists of 19 questions in 5 sections. The structure of the questionnaire survey is summarised in Table 2 .

Table 2: Questionnaire survey structure

\begin{tabular}{|l|c|l|}
\hline \multicolumn{1}{|c|}{ Section } & \multicolumn{1}{|c|}{$\begin{array}{c}\text { Questions } \\
\text { No. }\end{array}$} & \multicolumn{1}{c|}{ Descriptions } \\
\hline A. Respondents' details & $1.1-1.5$ & $\begin{array}{l}\text { Position, experience, type of shopping centre } \\
\text { scheme, role in decision-making, and current } \\
\text { occupancy status }\end{array}$ \\
\hline $\begin{array}{l}\text { B. Facilities Management } \\
\text { Service trends }\end{array}$ & $2.1-2.2$ & $\begin{array}{l}\text { Types of facilities management services, critical } \\
\text { to business operations and }\end{array}$ \\
\hline $\begin{array}{l}\text { C. Facilities Management } \\
\text { Service Delivery } \\
\text { Particulars }\end{array}$ & $3.1-3.8$ & $\begin{array}{l}\text { Current provision, primary reasons for in-house } \\
\text { and outsourcing }\end{array}$ \\
\hline $\begin{array}{l}\text { D. Management Perception } \\
\text { Towards Potential Benefits }\end{array}$ & $4.1-4.2$ & $\begin{array}{l}\text { Lists of potential benefits and potential risks that } \\
\text { influenced management decision towards the } \\
\text { best options of FM service delivery. }\end{array}$ \\
\hline
\end{tabular}




\begin{tabular}{|l|l|l|}
\hline $\begin{array}{l}\text { and Potential Risks of FM } \\
\text { Service Delivery }\end{array}$ & & \\
\hline E. General & $5.1-5.2$ & $\begin{array}{l}\text { Management awareness, intention, and } \\
\text { perceptions towards the best options for FM } \\
\text { service delivery }\end{array}$ \\
\hline
\end{tabular}

\subsection{Sample Selection}

The list of respondents was obtained from the Malaysia Shopping Mall Association (MSMA). According to MSMA, the total population of the shopping centres' scheme in the Klang Valley is about 113. The total numbers include the very large size shopping centres (25), large size shopping centres (41), medium size shopping centres (42) and small size shopping centres (5).

\subsection{Response Rate And Sample Size}

The sample size for this survey is one hundred eight $(\mathrm{N}=108)$. This includes very large size, large size and medium size of shopping centres. Small size shopping centre is excluded from this survey. Overall, this research managed to get 68 of returned questionnaires. This represented 52\% from the very large size shopping centre's population, $68 \%$ from the large size of shopping centre's population and $64 \%$ from the medium size shopping centres population. Overall those represented the total of an effective 63\% response rate (Table 3).

Table 3: Questionnaires Returned and Total Response Rate

\begin{tabular}{|c|c|c|c|}
\hline $\begin{array}{c}\text { Types of Shopping } \\
\text { Centres }\end{array}$ & $\begin{array}{c}\text { Questionnaires } \\
\text { Sent }\end{array}$ & $\begin{array}{c}\text { Questionnaires } \\
\text { Returned }\end{array}$ & Total Response Rate \\
\hline $\begin{array}{c}\text { Very Large size } \\
\left(80,000 \mathrm{~m}^{2} \text { and above }\right)\end{array}$ & 25 & $13(52 \%)$ & $12 \%$ \\
\hline $\begin{array}{c}\text { Large size } \\
\left(40,000 \mathrm{~m}^{2}-79,999\right. \\
\left.\mathrm{m}^{2}\right)\end{array}$ & 41 & $28(68 \%)$ & $26 \%$ \\
\hline $\begin{array}{c}\text { Medium size } \\
\left(20,000 \mathrm{~m}^{2}-39,999\right.\end{array}$ & 42 & $27(64 \%)$ & $25 \%$ \\
$\left.\mathrm{~m}^{2}\right)$ & & & $63 \%$ \\
\hline Total & 108 & 68 & \\
\hline
\end{tabular}

\section{RESULTS}

\subsection{Respondent Profiles}

For the respondent profiles, we can see that most of the shopping centre managers answered this survey are with experiences of 5-10 years (40) in managing their respective malls. Followed by with experiences of less than 5 years (15), and the least are 6 people with experiences of 11-15 years (see Table 4). This data is necessary to know how well each of the managers knows their complexes and their answer can contribute to the quality of the answered given. Besides, all of them also participate in the decision making for choosing the right FM service delivery for their respective shopping centre. 
Table 4: Shopping Centres Managers' work experienced $(\mathrm{N}=68)$

\begin{tabular}{|c|c|c|c|c|}
\hline $\begin{array}{l}\text { Working } \\
\text { Experience } \\
\text { (Years) }\end{array}$ & Less than 5 years & $5-10$ years & $11-15$ years & $\begin{array}{c}\text { More than 15 } \\
\text { years }\end{array}$ \\
\hline Total & 15 & 40 & 6 & 7 \\
\hline
\end{tabular}

\subsection{Types of F M Services Have Been Practiced in Klang Valley Shopping Centres}

There are eleven (11) services that fall under facilities management services in shopping centres include; Mechanical and engineering services, building and ground maintenance, cleaning and housekeeping services, energy and environmental management, health and safety management, information technology services, waste management, car park management, customer services, security services and landscaping services. Figure 1 shows the types of facilities management services have been practiced in Klang Valley shopping centres. Building and ground maintenance services $(\mathrm{n}=68,100 \%)$ are rated as the must have services provided by all shopping centres in the Klang Valley. Followed by cleaning and housekeeping services $(n=65,96 \%)$ and also security services $(n=65,96 \%)$. The least rated services are the energy and environment management $(n=38$, $56 \%)$.

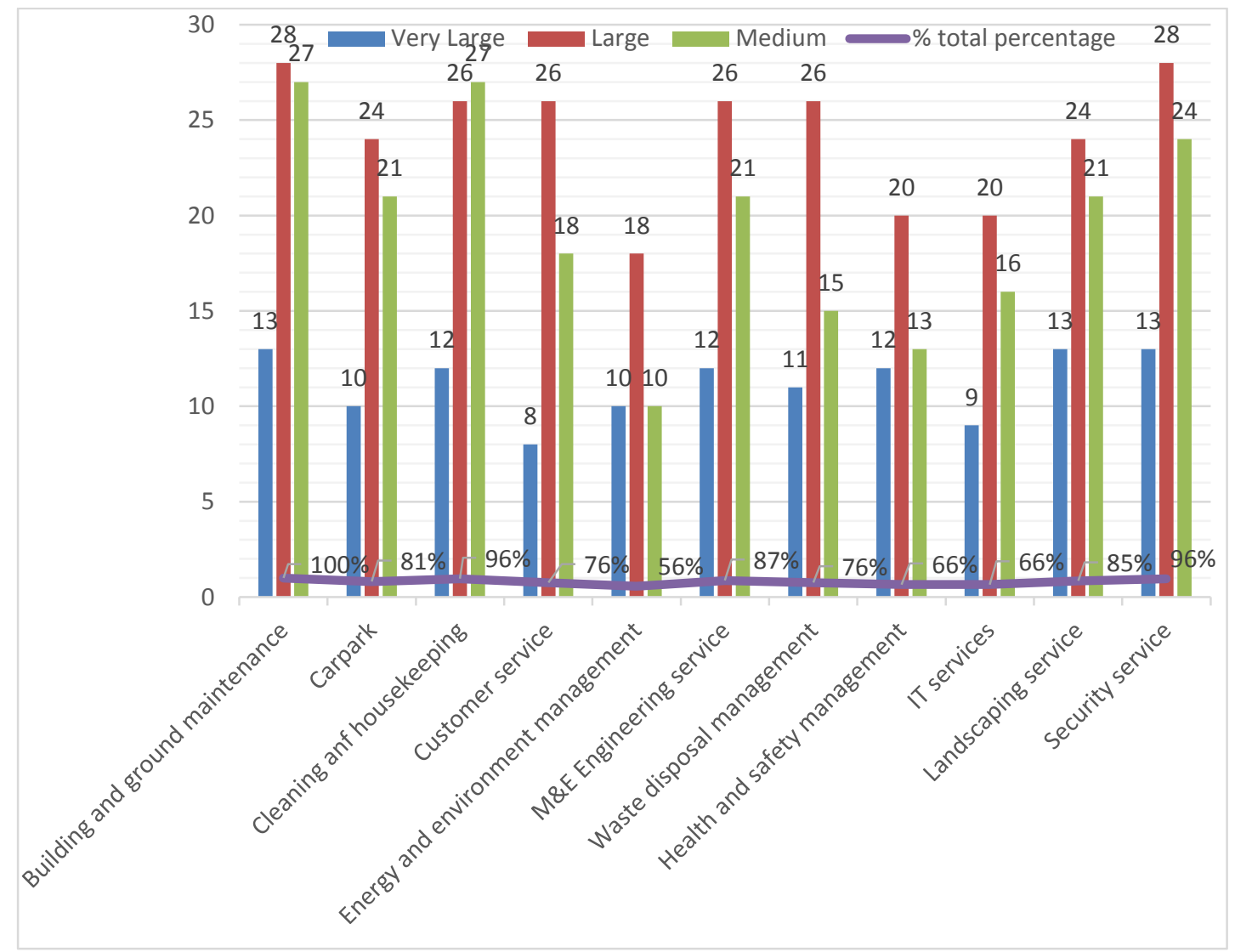

Figure 1: Type of FM services provided in the Klang Valley shopping centre 


\subsection{Criticality Of FM Services}

Table 5 shows the ranking for the criticality of the facilities management services based on the 3 different categories of the shopping centre which are very large, large and medium size. The results from table 5 show that all sized of shopping centre agreed that security services are very high critical services in their whole operation. No matter big or small sized of the shopping centre, they have to make sure that all the tenants and consumers feel safe, otherwise, the feeling of insecurity may weaken the mall's attractiveness and reputation (Overstreet and Clodfelter, 1995; Kajalo and Lindblom, 2006). The other FM service criticality is as shown in table 5 below.

Table 5: Criticality of FM services based on 3 sizes or categories of shopping centres

\begin{tabular}{|l|c|c|c|}
\hline \multicolumn{1}{|c|}{ Types of FM services } & Very Large size & Large size & Medium size \\
\hline Security services & Very high & Very high & Very high \\
\hline $\begin{array}{l}\text { Cleaning and housekeeping } \\
\text { services }\end{array}$ & Moderate & High & Very high \\
\hline $\begin{array}{l}\text { Building and ground } \\
\text { maintenance }\end{array}$ & High & Very high & Moderate \\
\hline M\&E engineering services & High & High & High \\
\hline Car park management & Very high & Very high & Moderate \\
\hline Customer services & Low & Low & Very low \\
\hline Health and safety management & High & High & High \\
\hline Landscaping services & Low & Moderate & Moderate \\
\hline Waste disposal management & High & High & High \\
\hline $\begin{array}{l}\text { Energy and environmental } \\
\text { management }\end{array}$ & Moderate & Very low & High \\
\hline $\begin{array}{l}\text { Information technology } \\
\text { services }\end{array}$ & Low & Low & Very low \\
\hline
\end{tabular}

Overall, results above indicate that the management of shopping centres is aware of the importance and how critical the FM services that need to be managed properly in their shopping centres. This is because some of the services are highly legislative demands such as health and safety management, energy and environmental management and waste management. Services and system such as security, cleaning, all the lighting, heating, ventilation, and air conditioning have to be in the best condition possible, which may critical to the success of any shopping centre (Muhlebach and Alexander, 2005). Basically, maintaining those services and system could affect the customer's expectation, or they will go elsewhere if amenities such as parking, cleanliness, landscaping and security always become the issues.

\subsection{Current Provisions Of FM Service Delivery In Klang Valley Shopping Centres}

Next analysis shows the current provision of FM services in Klang Valley shopping centres for both provisions of in-house provision and outsourcing, which distinguished according to the size or category of the shopping centre. Figure 2 shows the result of which services being practiced using in-house or outsourcing by very large sized shopping centre in Klang Valley. Followed by a large sized shopping centre (Figure 3) and medium sized 
shopping centre (Figure 4). In figure 2, it shows the current practice of FM services, particularly for a very large sized shopping centre. It can be seen that 7 out 11 services are being practiced using own internal staff rather than the other 4 services. The seven services include building and ground maintenance, car park, customer services, energy and environment management, M\&E Engineering services, health and safety management and lastly IT services. While for cleaning and housekeeping services, waste disposal management, landscaping, and security services are preferred to be practiced using outside providers. There are none at all for health and safety management and also customer services which practiced using in-house services for a very large sized shopping centre.

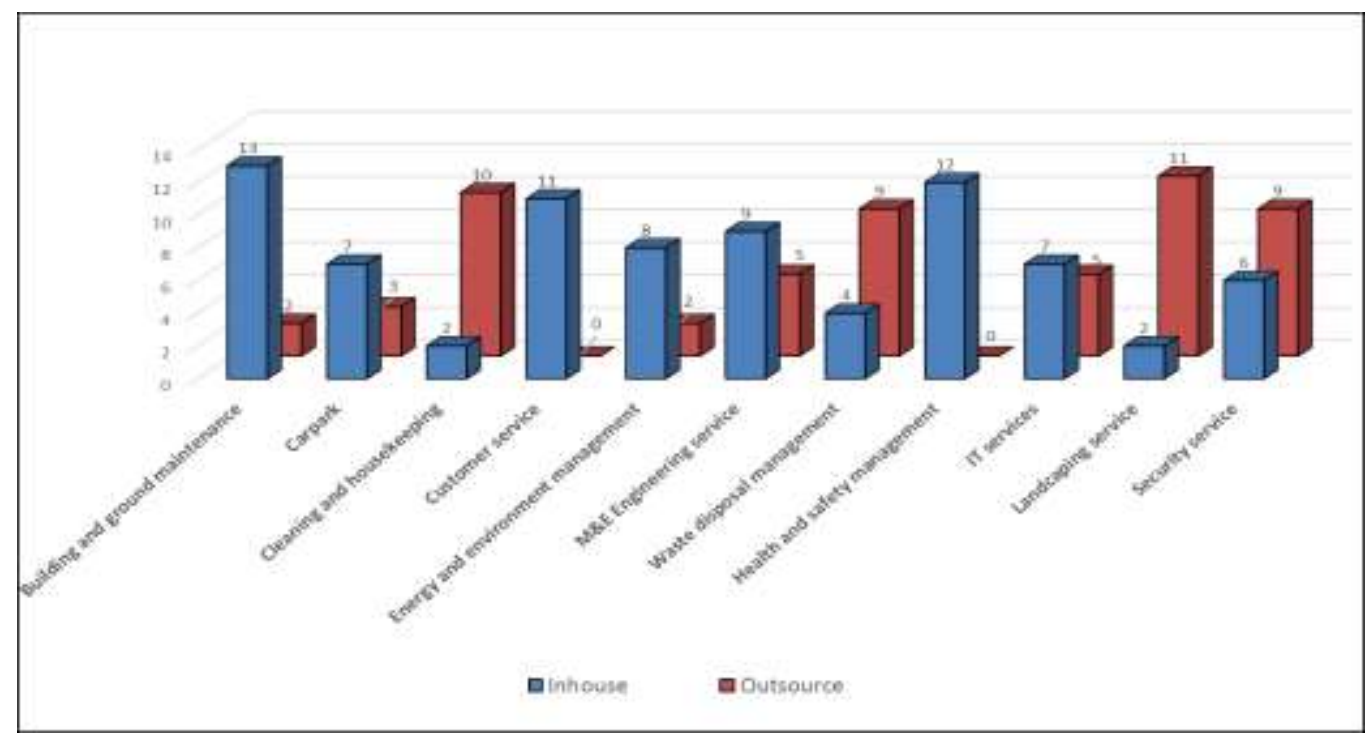

Figure 2: Current of FM service delivery practice in very large sized shopping centre $(\mathrm{N}=68)$

Meanwhile, for figure 3, it shows the current practice of FM services, particularly for the large sized shopping centre. It can be seen that 6 out 11 services are being practiced using own internal staff rather than the other 5 services. The six services include building and ground maintenance, car park, customer services, energy and environment management, M\&E Engineering services, lastly health and safety management. While for cleaning and housekeeping services, waste disposal management, landscaping, security services and included the IT services are preferred to be practiced using outside providers. Most of the respondents choose the building and ground maintenance and customer services as services that preferred to be practiced using inhouse service while waste management service as services preferred to be practiced using outside contractors.

Lastly, for medium sized shopping centre, figure 4 shows their current practice of FM services. It can be seen that 6 out 11 services preferred to be practiced using in-house services while the other 5 services using outsourcing procurement. The six services include building and ground maintenance, customer services, energy and environment management, $M \& E$ engineering service, health and safety management and lastly IT services. While for the car park, cleaning and housekeeping, waste disposal management, landscaping, and security services preferred to be practiced using the outsourcing method. 


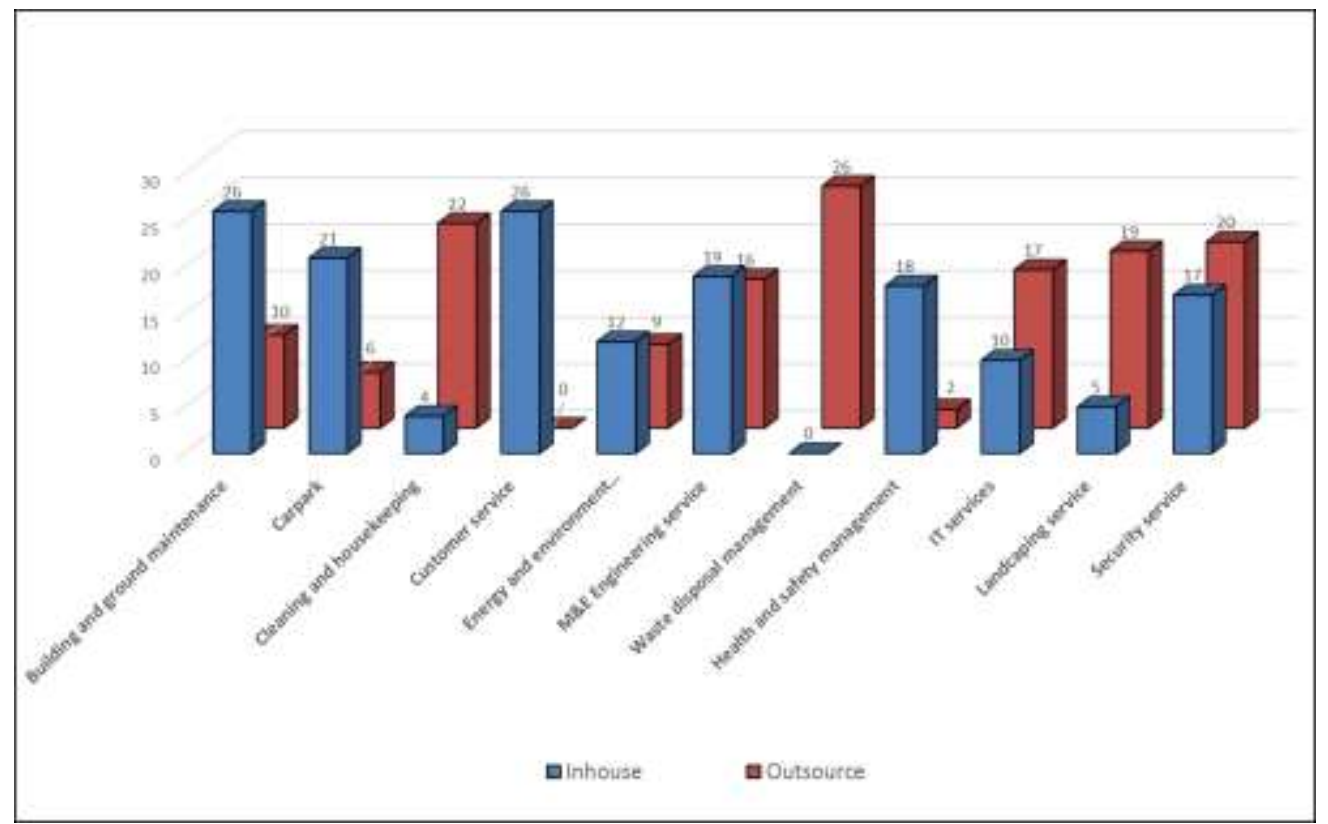

Figure 3: Current of FM service delivery practice in large sized shopping centre ( $N=68$

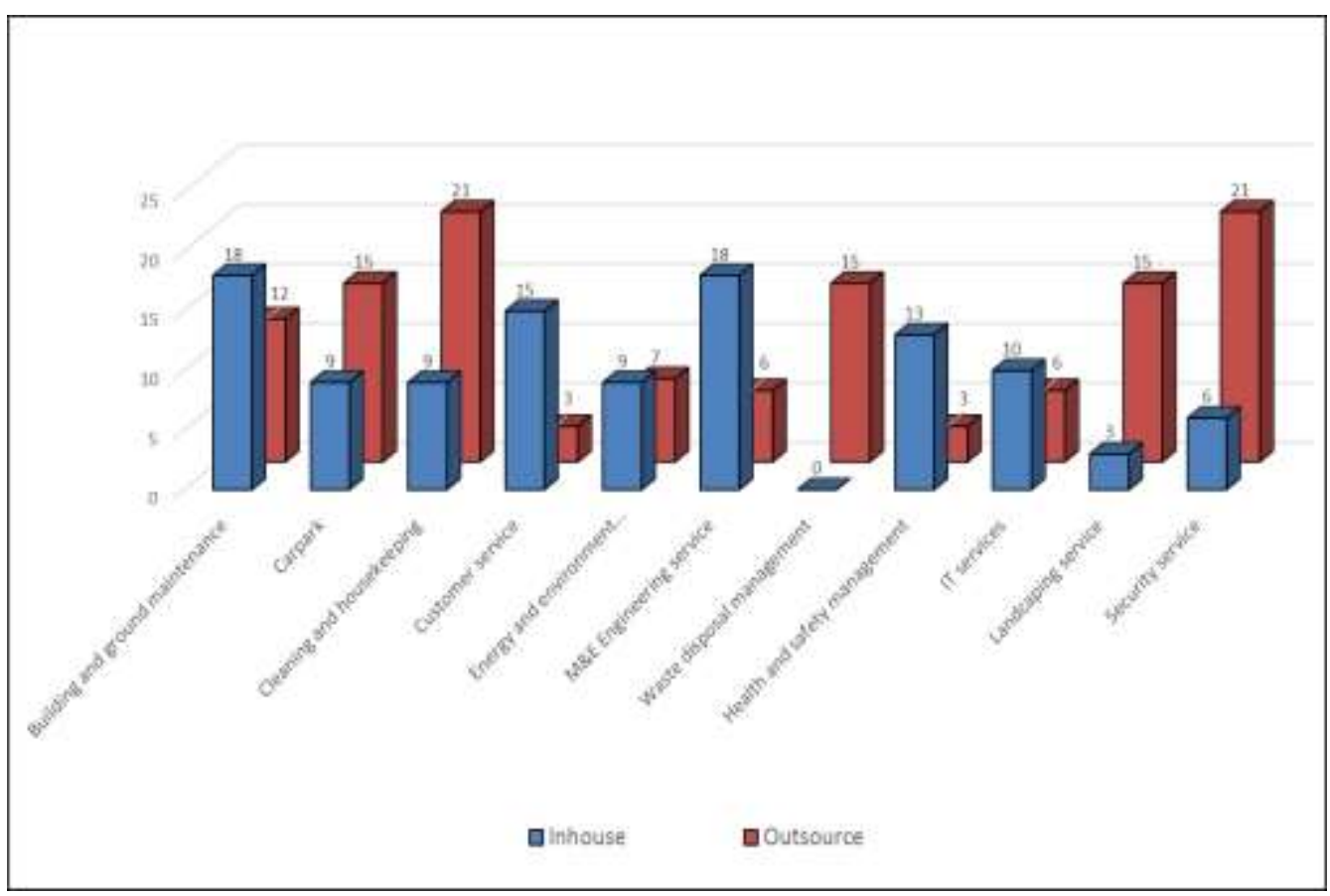

Figure 4: Current of FM service delivery practice in medium sized shopping centre $(\mathrm{N}=68)$. 
These results indicate that the FM service delivery still favor the in-house management teams to handle the services in the majority of shopping centres in Klang Valley. Not all non-core services are outsourced to FM providers. By keeping all activities in-house apparently, it is not a very cost-effective option. This is relatively static and standard fashion (Cant, 2005; Musa and Pitt, 2010). FM services in Klang Valley shopping centres are more likely to perceive the delivered solutions as being for operational matters rather than strategic matters. This is because shopping centres are generally considered to be in the custody of the property manager to ensure that the investment value of the property is optimized and the objectives of the investors are achieved (Musa and Pitt, 2009; Olajide et al, 2013).

Next analysis shows the primary reasons for the respondents in choosing either using internal staff or outsourcing the FM services to the service provider. The respondents were asked to choose and select more than one reason which they find applicable to their situation. Based on Musa (2011), most of the shopping centres in the UK selected cost saving as the most primary reason for outsourcing. The results from this research may vary from the other countries and may vary among the shopping centre especially in the Klang Valley. The results are analysed and show as in table 6 below:

Table 6: Primary reasons for practicing the FM services in-house

\begin{tabular}{|l|c|c|c|}
\hline Primary Reasons for In-house & Selected & Not selected & Total (N) \\
\hline Cost reduction & $86.8 \%(59)$ & $13.2 \%(9)$ & 68 \\
\hline Increase effectiveness & $52.9 \%(36)$ & $47.1 \%(32)$ & 68 \\
\hline Improve service quality & $51.5 \%(35)$ & $48.5 \%(33)$ & 68 \\
\hline Focus on core competencies & $38.2 \%(26)$ & $61.8 \%(42)$ & 68 \\
\hline $\begin{array}{l}\text { Developing staff } \\
\text { knowledge }\end{array}$ & $35.3 \%(24)$ & $64.7 \%(44)$ & 68 \\
\hline Availability of in-house labor force & $30.9 \%(21)$ & $69.1 \%(47)$ & 68 \\
\hline Staffing flexibility & $27.9 \%(19)$ & $72.1 \%(49)$ & 68 \\
\hline Increase customer satisfaction & $25 \%(17)$ & $75 \%(51)$ & 68 \\
\hline
\end{tabular}

For the primary reasons for choosing in-house (refer table 6), the overall result shows that the most selected primary reason to keep the services in-house is because of its help in cost reduction with the percentages of $86.8 \%$ (59 out of 68). The second and third reasons selected by 36 and 35 respectively shopping centre managers are to increase the staff work effectiveness by the percentage of $52.9 \%$ and also improving their service quality in managing the FM services. The least selected for primary reasons to keep FM services inhouse is to increase customer satisfaction (25\%). Table 7 otherwise shows the primary reasons for the management to choose outsourcing the services to outside providers. 
Table 7: Primary reasons for outsourcing

\begin{tabular}{|l|c|c|c|}
\hline Primary Reasons for outsourcing & Selected & Not selected & Total (N) \\
\hline Require specialist & $75 \%(51)$ & $25 \%(17)$ & 68 \\
\hline Reduce management burden & $64.7 \%(44)$ & $35.3 \%(24)$ & 68 \\
\hline Improve company focus on core business & $55.9 \%(38)$ & $44.1 \%(30)$ & 68 \\
\hline Resourced not available internally & $50 \%(34)$ & $50 \%(34)$ & 68 \\
\hline Difficult to manage & $35.3 \%(24)$ & $64.7 \%(44)$ & 68 \\
\hline Performance improvement & $33.8 \%(23)$ & $66.2 \%(45)$ & 68 \\
\hline Reduce and control operating costs & $22.1 \%(15)$ & $77.9 \%(53)$ & 68 \\
\hline Limited budget & $16.2 \%(11)$ & $83.8 \%(57)$ & 68 \\
\hline
\end{tabular}

Based on the results shown in table 7, it shows that 51 out of 68 managers choose the most selected primary reasons for outsourcing is because the management needs the specialist provider. The second high reasons choose by managers are because by outsourcing some of the services, it actually can help in term of reducing the management burden $(64.7 \%)$ since they can focus on other services which need more attention. The least selected reasons for outsourcing is because of the limited budget with percentages of $16.2 \%$. Since the budgeting is prepared early and the management has to decide which services need outside provider, hence it should be no problem for the management to have this issue.

\section{CONCLUSION}

Facilities management, service delivery in the Klang Valley shopping centre might be different from one shopping centre to another. It is may be due to differences in term of size of the shopping centre and also different in term of their management strategy. Each organization will have different needs and goals in managing their property, even within the same sectors.

The findings from this research showed that there are 11 types of FM services confirmed and currently being practiced in Klang Valley (KV) shopping centre, which include: building and ground maintenance, car park, cleaning housekeeping, customer service, energy and environment management, mechanical and engineering (M\&E) services, waste disposal management, health and safety, information technology (IT) services, landscaping and lastly security services.

Currently, security service is ranked as very high critical FM services for all sizes of the shopping centre. Most of Klang Valley shopping centres are identified delivering the FM services via both provisions that include inhouse and outsourced. However, the majority of Klang Valley shopping centres is still practicing most of the non-core activities in-house. To outsource the non-core areas to the FM service provider is predominantly a short-term solution. It is important that all parties take a fresh look, and perhaps consider the new models for the management and delivery of FM services in such a dynamic environment. It's also important to point out what are the main reason for choosing either in-house or outsourcing. Besides, the decision on choosing the FM service delivery in the Klang Valley shopping centre may vary from one shopping centre to another. This may be varied due to the sizes of the shopping centre and still depend on each of their management strategies and priority. There is no right and wrong decision, but what's important is that the property, the facilities, and amenities are running effectively. 


\section{REFERENCES}

Alexander, K. (1996). Facilities Management: Theory and Practice. London: E \& FN Spoon.

Atkin, B. (2003). Contracting Out or Managing Services In-house. Nordic Journal of Surveying and Real Estate Research: Special series, 1

Atkin, B., and Brooks, A. (2005). Total Facilities Management (2nd ed.). Oxford: Blackwell Publishing Ltd.

Barrett, P., and Baldry, D. (2000). Total Facilities Management. Oxford: Blackwell Science Limited

Barrett, P., and Baldry, D. (2003). Facilities management: Towards best practice (2 ${ }^{\text {nd }}$ ed). Oxford: Blackwell Publishing

Barrett, P., \& Baldry, D. (2009). Facilities management: Towards best practice: John Wiley \& Sons.

BIFM. (2010). Homepage of British Institute of Facilities Management.

Brandes, H., Lilliecreutz, J., \& Brege, S. (1997). Outsourcing-success or failure?: Findings from five case studies. European Journal of Purchasing \& Supply Management, 3(2), 63-75

Cant, M. (2005). Collaboration in infrastructure services in regional retail centres: Value-added contribution of facilities management at the Birmingham Bullring. Journal of Facilities Management, 215-225.

Chieng, S. L. A. S. A. (2013). The effects of Procurement Systems Toward Performance of the Refurbishment Projects. Paper presented at the 6th ASEAN Post Graduate Seminar, Kuala Lumpur.

Collings, T. (2007). Building and Operations Management. Paper presented at the NZPI CPD Seminar, Wellington

Connors, P. (2003). Innovation Process and Innovativeness in Facility Management Organisations Comparative Case Study, Wageningen University, Netherlands

Elmuti, D. (2003). The perceived impact of outsourcing on organizational performance. American Journal of business, 18(2), 33-42

Ghani, M.K., Hamid, Z., Ibrahim, I., Kamaruzzaman, S.N., \& Musa, Z.N. (2013). Defining the Critical Success Factor in FM Malaysian Healthcare Sector. in proceeding of the 3rd International Building Control Conference

Haris, S. Y., and Adnan, H. (2008). Facilities Management Challenges and Opportunities in the Malaysian Property Sector. Journal of Sustainable Development, 1(2), 79-85

IFMA, (2010). International Facility Management Association website. http://www.ifma.com

Jensen, P. A. (2011). Organisation of facilities management in relation to core business. Journal of Facilities Management, 9(2), 78-95

Kamaruzzaman, N. S., \& Zawawi, A. E. M. (2010). Development of facilities management in Malaysia. Journal of Facilities Management, 8(1), 75-81

Khoo, E. (2013). Facilities Management Procurement Practices in Klang Valley Shopping Centre. (Unpublished degree's thesis). University of Malaya, Kuala Lumpur, Malaysia

Krell, E. (2006). What's wrong with outsourcing (and how to fix it). Contrasting USA and Europe. European Management Journal, 20(2): 189-198

Kremic, T., \& Tukel, O. I. (2006). Assisting public organisations in their outsourcing endeavours: a decision support model. International Journal of Integrated Supply Management, 2(4), 383-406

Kurdi, M. K., Abdul-Tharim, A. H., Jaffar, N., Azli, M. S., Shuib, M. N., \& Ab-Wahid, A. M. (2011). Outsourcing in Facilities Management- A Literature Review. Procedia Engineering, 20(0), 445-457

Lavy, S., \& Shohet, I. M. (2010). Performance-based facility management-an integrated approach. International Journal of Facility Management, 1(1)

Mclvor R., (2000), A practical framework for understanding the outsourcing process, Supply Chain Management

Moore, M., \& Finch, E. (2004). Facilities Managament in South East Asia. Facilities 
Muhlebach, R. F., \& Alexander, A. A. (2005). Shopping Center Management And Leasing: Institute of Real Estate Management. 12, 17-20

Musa, Z. N., \& Pitt, M. (2009). An Introduction to the Facilities Management in UK Shopping Centre. Paper presented at the 4 th Annual Conference Liverpool BEAN

Musa, Z.N., (2011). Determining the Best Options for Facilities Management (FM) Service Delivery in UK Shopping Centres. Unpublished PhD thesis. Liverpool: Liverpool John Moores University

Nik Elyna and Pitt, M. (2014). Facilities management in Malaysia: Understanding the development and practice. Facilities, 32(9/10), 490-508

Noor, M., \& Pitt, M. (2009). A Critical review on innovation in facilities management service delivery. Facilities, 27, 211-228

Noor, M., \& Pitt, M. (2010). Defining facilities management in the Malaysia perspective. in proceeding of the 17th Annual ERES Conference.

Olajide, F. J., Afolarin, A. O., \& Beauty, J. I. (2013). Asessment of Factors Influencing Facility Management Procurement Route in Lagos State, Nigeria. Journal of Surveying, Construction and Property, 4(1).

Payne, T. (2000). Facilities management: A strategy for success: Chartridge Books Oxford.

Persatuan Pengurusan Kompleks Malaysia (PPKM). (2015). About PPKM. Retrieved on 2015, November 1 from http://www.ppkm.org.my/about-us/about-ppkm.aspx

Pitt, M., \& Tucker, M. (2008). Performance measurement in facilities management: driving innovation?. Property management, 26(4), 241-254.

Price, I. (2002). Can FM evolve? If not, what future? Journal of Facilities Management, 1, 56-69

Rodriguez, T. F. E. and M. R. Diaz. (2008). Effect of internal and relational capabilities on outsourcing: An integrated model. Industrial Management and Data Systems, 108(3): 328-345

Ruslan, N. (2007, August). Campus facilities management experience. In National Asset and Facilities Management (NAFAM) Convention, National Asset and Facility Management Development.

Syed Mustapa, S. A. H., \& Jusoff, K. (2009). Facility management challenges and opportunities in the Malaysian property sector. Journal of Sustainable Development, 1(2), 79.

Tay, L., \& Ooi, J. (2001). Facilities Management: a Jack of all trades? Facilities, 19(10), 357-362.

Yiu, C. Y. (2008). A conceptual link among facilities management, strategic management and project management. Facilities, 26, 501-511

Wise, D. (2007). Agility spotlight and leadership in project management. Project management institute (PMI), 60-61 